\title{
Indonesian EFL Teachers' Classroom Assessment Methods in Reading
}

\author{
Saefurrohman, Ph.D \\ English Education Department, Universitas Muhammadiyah Purwokerto \\ Email: saefurrohman@ump.ac.id
}

\begin{abstract}
The aim of this study was to find out the EFL teachers classroom assessment methods in reading. A mixed method design was used to answer the research questions. The participants of this study were taken from six high schools of Banyumas Regency. Qualitative and quantitative data collections were done concurrently, meaning that a particular sequence was not followed. The quantitative approach gathered data about teacher classroom assessment method in reading. Quantitative data collection was employed using survey. While, the qualitative approach using interview, observation and document analysis was utilized to further examine what and how Indonesian classroom assessment method was employed. Survey data were analyzed by descriptive and inferential statistical methods and thematic data analysis was used in analyzing all the qualitative data. From the study it can be concluded that among the Indonesian English teachers, multiple choice was the priority teacher-made reading assessment used with a mean of 3.33. For students-constructed assessment, the most popular methods used among Indonesian English teachers was oral interview/questioning with a mean of 3.29 and 3.25 respectively.
\end{abstract}

Key words : Reading, Classroom assessment, methods

\section{Introduction}

The EFL teachers in Indonesia realize that classroom assessment methods should be viewed as a process rather than as a product in which assessment purpose is not only a matter of getting the students' score and determining whether they pass the requirements or not but it is more on how to know the students' progress in learning and mediating them to get success in learning.

With this current paradigm, the practices of classroom assessment methods have brought a lot of changes in the way educators perceive it, especially in reading. According to Lin and Tsai (2012), assessment methods refer to "any of a variety of procedures used to obtain information about student performance". There are quite a number of assessment methods with each one of them involving a particular purpose for its use, and Cheng and $\mathrm{Hu}$ (2004) have categorized these assessment methods under; teacher-made assessment/traditional, students-conducted assessment alternative assessment and standardized test

This study explored on how English teachers in Indonesia practice their classroom assessment methods in EFL classes

\section{Methods of research}

A mixed method design, as described by Creswell (2008), was used to answer the research questions. The participants of this study were taken from six high schools of Banyumas Regency. Qualitative and quantitative data collections were done concurrently, meaning that a particular sequence was not followed. The quantitative approach gathered data about teacher classroom assessment method in reading. Quantitative data collection was employed using survey. While, the qualitative approach using interview, observation and document analysis was utilized to further examine what and how Indonesian classroom assessment method was employed. Survey data were analyzed by descriptive and inferential statistical methods and thematic data analysis using Creswell model (2008) was used in analyzing all the qualitative data.

\section{Result and Discussion}

\section{Result}

In this section, and Indonesian teachers' classroom assessment practices in reading, writing, and speaking and listening are reported. Three categories were used to categorize the findings in each skill, namely: teacher-made assessment methods, student-conducted assessment methods, standardized testing in reading. 
Teacher-made assessment methods in these articles refer to those assessment methods designed and administered by teachers, whereas student-conducted assessment methods are those that directly involve students' participation in the assessment process. It should be pointed out that other terms such as select, supply-type or performance-based assessments also exist to refer to the different assessment methods in the field of education (Wilson, 2002). The above three categories were chosen as they best summarize the assessment methods reported in this survey using likert chart scale.

Teachers' classroom assessment methods in reading are presented in table 1 . As can be seen in table 1, among the Indonesian English teachers, multiple choice was the priority teacher-made reading assessment used with a mean of 3.33. This is also supported by the percentage distribution result in which $50 \%$ of respondents always used it. Moreover, $54.17 \%$ of Indonesian English teachers also used sentence completion items more often to assess reading. On the other hand, matching items and interpretative items (e.g. reading passage; interpret a map or a set of directions) were not much used, with $50 \%$.

Read aloud/dictation followed by oral interview/discussion became the priority of Indonesian teachers when doing reading assessment with a mean of 3.29 and 3.25 respectively, with percentage distribution showed that $50 \%$ of respondents always used this. This was then followed by students' summary of what is read with mean of 3.04. In contrast student journal, student portfolio, peer and self assessment were not much used by Indonesian teachers in assessing reading, with the mean was less than 3.00. Finally, Indonesian English teachers also used standardized reading tests to assess reading with half of the respondents $(50 \%)$ indicated that they always used them.
Table 1. Frequency and Percentage Distribution Indonesian English Teachers' Classroom Assessment Methods in Reading

\begin{tabular}{|c|c|c|c|c|c|c|c|c|c|}
\hline \multirow{2}{*}{$\begin{array}{c}\text { Methods used to } \\
\text { assess reading }\end{array}$} & \multicolumn{2}{|c|}{ Always } & \multicolumn{2}{|c|}{ Quite a lot } & \multicolumn{2}{|c|}{ Not Much } & \multicolumn{2}{|c|}{ Never } & \multirow{2}{*}{$\begin{array}{c}\text { Mea } \\
\text { n }\end{array}$} \\
\hline & $\mathbf{n}$ & $\%$ & $\mathbf{n}$ & $\%$ & $\mathbf{n}$ & $\%$ & $\mathbf{n}$ & $\%$ & \\
\hline \multicolumn{10}{|l|}{ Teacher-made } \\
\hline cloze items & 7 & $29.17 \%$ & 11 & $45.83 \%$ & 6 & $25.00 \%$ & 0 & $0 \%$ & 3.04 \\
\hline $\begin{array}{l}\text { sentence completi } \\
\text { items }\end{array}$ & 4 & $16.67 \%$ & 13 & $54.17 \%$ & 7 & $29.17 \%$ & 0 & $0 \%$ & 2.87 \\
\hline true-false items & 5 & $20.83 \%$ & 11 & $45.83 \%$ & 8 & $33.33 \%$ & 0 & $0 \%$ & 2.87 \\
\hline matching items & 4 & $16.67 \%$ & 7 & $29.17 \%$ & 12 & $50 \%$ & 1 & $4.17 \%$ & 2.58 \\
\hline multiple-choice iten & $\begin{array}{l}1 \\
2\end{array}$ & $50 \%$ & 8 & $33.33 \%$ & 4 & $16.67 \%$ & 0 & $0 \%$ & 3.33 \\
\hline $\begin{array}{l}\text { interpretative items } \\
\text { (e.g. reading passage; } \\
\text { interpret a map or a } \\
\text { set of directions) }\end{array}$ & 3 & $12.50 \%$ & 7 & $29.17 \%$ & 12 & $50 \%$ & 2 & $8.33 \%$ & 2.45 \\
\hline $\begin{array}{l}\text { forms such as an } \\
\text { application form or an } \\
\text { order form of some } \\
\text { kind }\end{array}$ & 9 & $37.5 \%$ & 10 & $41.67 \%$ & 4 & $16.67 \%$ & 1 & $4.17 \%$ & 3.12 \\
\hline short answer items & 9 & $37.5 \%$ & 7 & $29.17 \%$ & 6 & $25.00 \%$ & 2 & $8.33 \%$ & 2.95 \\
\hline $\begin{array}{l}\text { editing a piece of } \\
\text { writing }\end{array}$ & 5 & $20.83 \%$ & 8 & $33.33 \%$ & 9 & $37.50 \%$ & 2 & $8.33 \%$ & 2.66 \\
\hline \multicolumn{10}{|l|}{ Students Conducted } \\
\hline Read aloud/dictation & $\begin{array}{l}1 \\
2 \\
\end{array}$ & $50 \%$ & 7 & $29.17 \%$ & 5 & $20.83 \%$ & 0 & $0 \%$ & 3.29 \\
\hline $\begin{array}{l}\text { Oral } \\
\text { interviews/questionin } \\
\mathrm{g}\end{array}$ & $\begin{array}{l}1 \\
0\end{array}$ & $41.67 \%$ & 10 & $41.67 \%$ & 4 & $16.67 \%$ & 0 & $0 \%$ & 3.25 \\
\hline $\begin{array}{l}\text { Student summaries of } \\
\text { what is read }\end{array}$ & 8 & $33.33 \%$ & 10 & $41.67 \%$ & 5 & $20.83 \%$ & 1 & $4 \%$ & 3.04 \\
\hline Student journal & 4 & $16.67 \%$ & 6 & $25.00 \%$ & 12 & $50 \%$ & 2 & $8 \%$ & 2.50 \\
\hline Student portfolio & 6 & $25.00 \%$ & 6 & $25.00 \%$ & 10 & $41.67 \%$ & 2 & $8.33 \%$ & 2.66 \\
\hline Peer assessment & 7 & $29.17 \%$ & 8 & $33.33 \%$ & 9 & $37.50 \%$ & 0 & $0.00 \%$ & 2.91 \\
\hline Self assessment & 6 & $25.00 \%$ & 6 & $25 \%$ & 12 & $50 \%$ & 0 & $0 \%$ & 2.75 \\
\hline $\begin{array}{l}\text { Standardized reading } \\
\text { tests }\end{array}$ & $\begin{array}{l}1 \\
2 \\
\end{array}$ & $50 \%$ & 9 & $37.50 \%$ & 3 & $12.50 \%$ & 0 & $0.00 \%$ & 3.25 \\
\hline
\end{tabular}

\section{Discussion}

Based on the findings the most popular teacher constructed reading assessment method Indonesian English teachers was multiple choice tests. This was also supported by the result of the interviews in which multiple choice tests was likely to be the most popular assessment method that was prepared by both teacher respondents:

"mostly I used multiple choice test in reading"

"After certain period of teaching, I always conduct paper and pencil based test such as multiple choice to check my students understanding" 
These interview results were also supported by students' statements on their teachers reading assessment method:

\section{"In reading, my teacher gives me a test in multiple choices"}

"Multiple choice is the test that is used by my teacher to test reading"

Multiple-choice tests have been used extensively in recent years for assessment purposes, most particularly in large classes where marking can consume inordinate amounts of time and resources. Multiplechoice tests have reportedly been used to good effect in courses (e.g Kuechler \& Simkin, 2003).

Research also indicated that many instructors appear to use multiple choice assessments as a preferred assessment tool. In teaching English, for example, investigators estimate multiple choice test usage for student assessments of between 65\% and 80\% (Higgins and Tatham, 2003). The actual number is higher today because multiple choice assessments are so ubiquitous across the other disciplines and also because they are now used so frequently on entrance examinations, online (Web-based) tests, mass-lecture courses, and certification tests (Higgins and Tatham, 2003).

Another reason related to the frequent use of multiple choice test is its advantages for teachers. These advantages include: (1) the ease and accuracy with which such tests can be machine graded (or regarded) and returned to students on a timely basis, especially in large classes; (2) the ability to create multiple versions of the same examination, thereby better enabling instructors to control cheating; (3) the ability to evaluate a test itself on a question by- question basis; (4) the ease with which correct answers can be verified; and (5) the ability to cover a wide range of material.

For students-constructed assessment, the most popular methods used among Indonesian English teachers was oral interview/questioning. This quantitative finding was supported by the classroom observation result in which some and Indonesian English teachers had an impressive ability to gather information on student understanding via oral discussion/ questioning during a reading class.

Classroom observation result showed that teachers questioned students frequently throughout the class period, asking students many different probing questions. They would not come out and tell them the answer or what they did wrong but instead questioned them to get further clarification and assist the students in figuring out their own mistakes and misconceptions. This questioning technique did not only help inform them of their understanding but also helped inform the students. Furthermore, they also questioned with ease, moving from one student to another, having them build off each other's ideas. These starter activities took place at the beginning of each class and lasted approximately ten to fifteen minutes allowing many opportunities for teachers to move around the room, at times, talking to almost every student in class either during individual work time or during the whole class discussion that followed.

The role of questions to improve students' understanding has been recognized for centuries and the use of questioning in teaching is as old as the Greek Philosopher, Socrates in the fifth century B.C (Harrop \& Swinson, 2003). Moreover, Harrop \& Swinson (2003) found that approximately $80 \%$ of a teacher's teaching in school was spent in asking questions. Recent research on teacher questioning behaviors and patterns shows that this has not changed, In other words, classrooms are still dominated with mostly teacher talk (Adedoyn, 2010).

Questions serve many purposes, such as provoking students to listen carefully, analyzing their thoughts and think critically (Adedoyn, 2010), initiating discussion and review material (Bullock, \& Stables, 2002), as well as challenging students to discover their ideas, inviting students to take risks, motivating and evaluating students (Schurr, 2000). The issue of questioning has also received attention in contemporary studies of education (e.g., Harrop \& Swinson, 2003; Ilaria, 2002). The importance of questioning cannot be underestimated. Ilaria (2002) for instance, deems that questioning is an important strategy in establishing a classroom atmosphere that is conducive to developing critical thinking among students.

Some researchers have conducted general investigations of the role of classroom questioning and have drawn the conclusions that assessment which includes posing questions during lessons is more effective in producing achievement gains than instruction carried out without questioning students. Students also perform better on test items previously asked as recitation questions than on items they have not been exposed to before. Futhermore, Oral questions posed during classroom recitations are more effective in fostering learning than are written questions Questions which focus student attention on salient elements in the lesson result in better comprehension than questions which do not (Harrop \& Swinson, 2003; Ilaria, 2002).

All in all, it is not surprising that questioning has been thought to be a good measure of a teacher's classroom assessment practice among Indonesian EFL Teachers 


\section{Conclusion}

From the study it can be concluded that among the Indonesian English teachers, multiple choice was the priority teacher-made reading assessment used with a mean of 3.33. For students-constructed assessment, the most popular methods used among Indonesian English teachers was oral interview/questioning with a mean of 3.29 and 3.25 respectively.

\section{References}

Adedoyin, Omobola. (2010). An Investigation of The Effects of Teachers' classroom Questions on the Achievements of Students in Mathematics: Case Study of Botswana Community Junior Secondary Schools. European Journal of Educational Studies 2(3), 2010. ISSN 19466331. Ozean Publication.

Bullock, K. and Stables, A., 2002. Teachers' Beliefs and Practices in Relation to their Beliefs about Questioning at Key Stage 2. Educational Studies, 28 (4), 371--384.

Cheng, Liying., Rogers, Todd., \& Hu, Huiqin. (2004). ESL/EFL Instructors' Classroom Assessment Practices: Purposes, Methods, and Procedures Language Testing 2004 21: 360. DOI: 10.1191/02655322041t288oa. http://ti.sagepub.com/content/21/3/360.

Creswell, J. W. (2008). Educational Research: Planning, Conducting, and Evaluating Quantitative And Qualitative Research. (pp. 256-259). Upper Saddle River, New Jersey: Pearson Prentice Hall.

Harrop, A., \& Swinson, J. (2003). Teachers' questions in the infant, junior and secondary school, Educational Studies, 29(1). 49-57.

Higgins, E., and Tatham, L. (2003). Assessing by multiple choice question (MCQ) tests at Manchester Metropolitan University. Retrieved from: http://www.celt.mmu.ac.uk/ltia/issue4/higginstat $\underline{\text { ham.shtml }}$
Ilaria, D. R. (2002). Questions that engage students in mathematical thinking. Proceedings of the annual meeting (of the) North American Chapter of the International Group for the Psychology of Mathematics Education (24th, Athens, GA, October 26-29, 2002). Vol. 1-4; SE 066887.

Kuechler, W. L. \& Simkin. M. G. (2003). How Well Do Multiple Choice Tests Evaluate Student Understanding in Computer Programming Classes? Journal of Information Systems Education. West Lafayette: Winter 2003. Vol. 14, Iss. 4; p. 389

Lin ,Qiu-Feng \& Tsai, Yea-Ru . (2012). Investigating the Effects of Applying Monitoring Strategy in EFL Writing Instruction. International Journal of Business and Social Science Vol. 3 No. 13; July 2012.

Schurr, S. (2000). How to improve discussion and questioning practices: Tools and techniques. Staff development kit \#2. Westerville, Ohio: National Middle School.

Wilson, S (2002) Comparing peer, self and tutor assessment in a course for university teaching staff. Paper presented at the learning Communities and Assessment Cultures Conference, University of Northumbria 28-30 August 2002 